STUDII

\title{
ACTIO REDHIBITORIA ȘI INFLUENȚA \\ ACESTEIA ASUPRA DREPTULUI ROMÂNESC
}

DOI: 10.24193 /SUBBiur.65(2020).4.21

Data publicării online:

16.03 .2021

\section{Dan OANCEA, Sorin Alexandru VERNEA, Vlad-Victor OCHEA*}

Rezumat: Prin acest articol, autorii își propun să expună elementele esențiale ale configurației actio redhibitoria în dreptul roman și să stabilească o legătură față de mai noile prevederi din dreptul român.

În acest scop, au fost avute în vedere reglementările din Digestele împăratului Iustinian, alături de prevederile celor mai importante legi din cea de-a doua fază a regimului turco-fanariot: Codul Calimach (1817) și Legiuirea Caragea (1818). În mod similar, sunt expuse succint și prevederile Codului Civil din 1864 și ale Codului civil din 2009. În considerentele finale, autorii analizează influența actio redhibitoria în dreptul român actual.

Cuvinte cheie: actio redhibitoria, garanția pentru vicii ascunse, drept român modern, influența romană,

* Prof. univ. dr. Dan Oancea, Facultatea de Drept, Universitatea din București, dan.oancea@drept.unibuc.ro; asist. univ. dr. Sorin-Alexandru Vernea, Facultatea de Drept, Universitatea din București, vernea.sorin-alexandru@drept.unibuc.ro; drd. Vlad-Victor Ochea, colaborator extern Facultatea de Drept, Universitatea din București, vladvictor.ochea@drept.unibuc.ro. 


\title{
THE REDHIBITORY ACTION AND ITS INFLUENCE IN ROMANIAN LAW
}

\begin{abstract}
By this paper, the authors aim to point out the essential elements that configure actio redhibitoria under Roman Law to relate them to the provisions of modern Romanian Law.

To this end, the relevant provisions from The Digests of Emperor Justinian are analyzed, alongside the provisions of the most important Laws of the Second Phase of the Turkish-Fanariot Regime, namely the Calimach Code (1817) and the Caragea Law (1818). Likewise, the provisions of the Civil Codes, from 1864 and 2009, are briefly pointed out, followed by final considerations regarding the influence of actio redhibitoria on current Romanian Law.
\end{abstract}

Keywords: Actio redhibitoria, warranty against defects, modern Romanian Law, Roman influence.

\section{Cuprins}

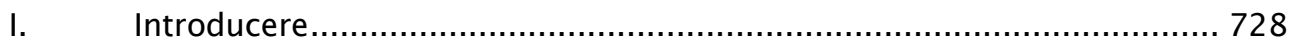

II. Edictele edililor curuli. Apariția actio redhibitoria............................. 729

III. Legiuirile adoptate în cea de-a doua fază a regimului turco-fanariot ..... 735

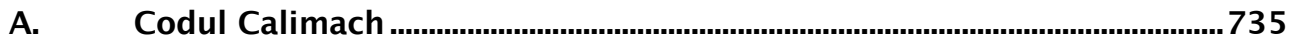

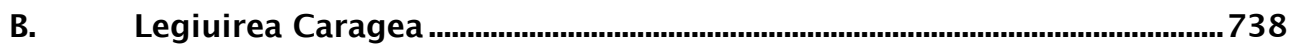

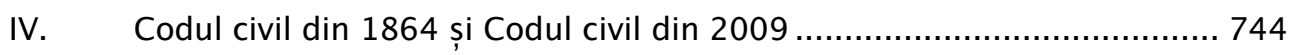

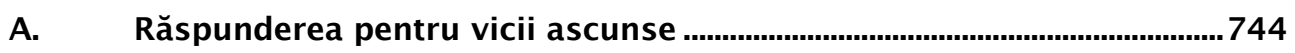

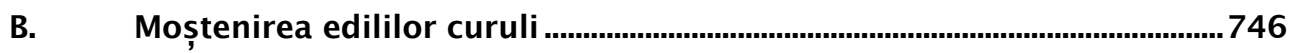

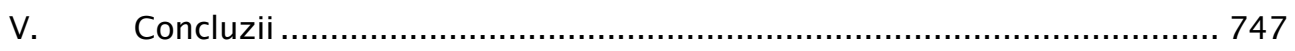




\section{Introducere}

Importanța instituțiilor elaborate în sfera teoriei obligațiilor în dreptul roman este incontestabilă pentru analiza modului de formare și dezvoltare a dreptului privat continental.

Prezenta lucrare urmărește să identifice elementele esențiale pentru configurarea acțiunii redhibitorii în dreptul roman, urmând a le raporta la prevederile dreptului românesc modern.

În acest scop, prima parte a lucrării va identifica principalele elemente definitorii ale actio redhibitoria în dreptul roman, folosind ca reper Digestele, urmând ca aceste elemente să fie raportate la prevederile relevante ale Codului Calimach şi Legiuirii Caragea, ca exponente ale reglementărilor din cea de-a doua fază a regimului turco-fanariot și, în final, la prevederile relevante ale Codurilor civile românești moderne.

Ultima parte va fi destinată unor concluzii referitoare la influența textelor romane asupra dreptului românesc modern, în privința configurării acțiunii redhibitorii. 


\section{Edictele edililor curuli. Apariția actio redhibitoria}

Creație a edililor curuli, actio redhibitoria, alături de actio quanti minoris ${ }^{1}$, a sancționat, inițial, obligația de garanție contra viciilor sclavilor și animalelor de povară vânduți pe piețele Romei.

După cum rezultă chiar din denumirea acesteia, actio redhibitoria tinde la desființarea contractului, iar efectul său este o restitutio in integrum, prin care părțile sunt repuse în situația anterioară încheierii convenției².

Grație ocrotirii superioare pe care o oferea cumpărătorului, în raport cu sistemul dreptului civil, actio redhibitoria a fost generalizată, aceasta putând fi intentată de orice cumpărător, contra oricărui vânzător, cu privire la orice lucru vândut.

Magistrați însărcinați cu poliția târgurilor și învestiți cu jurisdicția asupra litigiilor ivite cu ocazia actelor încheiate în piețe, edilii curuli au căutat să creeze un mecanism apt a-i feri pe cumpărători de pagubele pe care le-ar putea suferi ca urmare a dobândirii unor lucruri care prezentau vicii ascunse.

Întrucât dă cea mai înaltă expresie juridică protecţiei cumpărătorului, sistemul de garanție contra viciilor, introdus prin edictele edililor curuli și perfecționat de jurisprudență, și-a găsit un loc aparte în dreptul românesc, fiind preluat ca atare și completând galeria instituțiilor juridice romane care au fost receptate integral în diversele etape de evoluție a dreptului românesc.

\footnotetext{
${ }^{1}$ Această acțiune constituia o alternativă la desființarea vânzării și restituirea lucrului, respectiv prețului, cumpărătorul având posibilitatea de a păstra lucrul, dar de a cere de la vânzător diferența dintre prețul plătit și valoarea (diminuată) a lucrului afectat de vicii.

${ }^{2}$ G.May - Elements de Droit Romain, 11eme edition, Recueil Sirey, Paris, 1913, pg.352.
} 
Anterior inovației acestor magistrați3 ${ }^{3}$ în cadrul vânzării prin mancipațiune, vânzătorul nu răspundea față de cumpărător decât în ipoteza vânzării unui teren, atunci când îi transmitea o suprafață mai mică decât cea declarată sau dacă declara că fondul este liber, deși, în realitate, acesta era grevat cu servituți. În primul caz, el era obligat, prin actio de modo agri, la plata valorii dublului suprafeței lipsă, iar în cel de-al doilea caz, la plata dublului prețului, prin actio auctoritatis. Ambele acțiuni aveau un fundament delictual.

În rest, în vechiul drept roman, vânzătorul nu datora garanție contra viciilor.

Ulterior, obligația de garanție a fost asumată printr-o stipulațiune, alăturată mancipațiunii sau celor două stipulațiuni din care izvorau obligația de predare a lucrului, respectiv obligația de plată a prețului. Cu timpul, încheierea stipulațiunii pentru vicii a devenit obligatorie, apoi subînțeleasă.

$\mathrm{Cu}$ toate acestea, vânzătorul de bună-credință - care nu cunoștea existența viciilor - era ținut să răspundă doar dacă o stipulațiune specială fusese încheiată în acest scop.

În condițiile unei bogate oferte de mărfuri, exista şi riscul cumpărătorilor de a fi păcăliți de negustori rapace ${ }^{4}$, fie ei cetățeni, fie peregrini. Se pare că pe cei din urmă edilii curuli îi priveau mare îndoială.

3 P.F. Girard, Manuel élémentaire de droit romain, huitieme édition revue et mise a jour par Félix Senn, Paris, Librairie Arthur Rousseau, 1929, p. 598-599, și E. Molcuţ, D. Oancea - Drept roman, București, Casa de editură și presă Șansa S.R.L., 1993, p. 278-279.

4 D.21.1.44.1. 
În acest context au fost date cele două edicte: de mancipiis vendundis ${ }^{5}$ şi de jumentis vendundis, care au consacrat actio redhibitoria și actio quanti minoris ${ }^{6}$.

Potrivit celui dintâi, „cei care vând sclavi trebuie să îl informeze pe cumpărător despre bolile și defectele lor, să declare dacă sunt fugitivi, dacă nu cumva au provocat pagube ori au comis delicte din cauza cărora ar putea încă să fie urmăriți prin acțiunea noxală. Toate aceste lucruri trebuie să fie declarate onest la momentul vânzării. Dacă un sclav a fost vândut contrar acestei dispoziții sau dacă se încalcă ceea ce a fost declarat și promis în această privință în momentul vânzării și din această cauză cumpărătorul şi toți cei cărora sclavul le va aparține trebuie dezdăunați, vom da o acțiune prin care vânzătorul va fi condamnat la a-şi lua sclavul înapoi. Dacă sclavul vândut a fost, după momentul vânzării și predării, vătămat prin culpa cumpărătorului, a unuia dintre sclavii săi sau a reprezentantului său sau dacă, după vânzare, sclavul vândut i-a procurat cumpărătorului fructe sau a condus la dobândirea unui lucru de către cumpărător, dacă este vorba despre o sclavă care a adus pe lume un copil sau, în general, dacă a survenit orice accesoriu al lucrului vândut care îi mărește valoarea, cumpărătorul va fi obligat să țină seama de toate acestea în raport cu vânzătorul. Pentru acelaşi motiv, dacă cumpărătorul a fost obligat să plătească ceva din cauza sclavului vândut, vânzătorul va ține seama de aceasta. La fel, dacă sclavul se face vinovat de un delict pedepsit cu

5 Edictul a fost introdus la începutul secolului II î.e.n. A se vedea, în acest sens, R. Zimmermann, The Law of Obligations. Roman Foundation of the Civilian Tradition, Oxford University Press, 1996, p. 311, nota de subsol 113, apud A. de Senarclens, La date de l'Édit des édiles de mancipiis vendundis, 1923, în Tijdschrift voor Rechtsgeschiedenis.

${ }^{6}$ Se pare că acțiunile au fost create după apariția procedurii formulare (prin legea Aebutia, între anii 149-126 î.e.n., și prin legile Iuliae judiciariae din anul 17 î.e.n.), cf. P.F. Girard, op.cit., p. 600 . 
moartea, dacă a atentat asupra vieții vânzătorului, dacă a fost angajat să lupte cu bestiile în arenă, toate acestea trebuie declarate de vânzător, pentru că toate acestea dau loc acțiunii în restituire. Aceeași acţiune va fi dată și împotriva tuturor celor care au vândut rea-credință sclavi, cunoscând viciile acestora" 7 .

Potrivit celui de-al doilea edict, „cei care vând animale de povară trebuie să declare în mod public ce boală sau defect au acestea; dacă le-au înhămat pentru a fi vândute mai bine, le vor preda cumpărătorului în starea în care se găsesc. În caz de încălcare, vom da o acțiune contra vânzătorului, în curs de șaizeci de zile, fie pentru a-l obliga la predarea harnașamentului, fie la a-și lua animalul înapoi. În caz de boală sau de alt defect, vom da o acțiune contra vânzătorului în curs de șase luni pentru a-l constrânge la rezoluțiunea vânzării sau în curs de un an pentru a-l obliga la plata diferenței dintre prețul animalelor și valoarea acestora la momentul vânzării. Dacă se vinde o pereche

\footnotetext{
7 D.21.1.1: „qui mancipia rendunt, certiores faciant emptores, qui morbi vitiive cuique sit, quis fugitivus, errove sit, noxave solutus not sit. Eademque omnia cum ea mancipia venibunt, palam recte pronuntiatio. Quod si mancipium adversus ea venisset, sive adversus quod dictum promissumve fuerit, cum veniret, fuisset: quod ejus praestari oportere dicetur emptori, omnibusque ad quos ea res pertinet, judicium dabimus, ut id mancipium redhibeatur. Si quid autem post venditionem traditionemque deterius emptoris opera familiae, procuratorisve ejus factum erit: sive quid ex eo post venditionem natum, adquisitum fuerit, et si quid aliud in venditione ei accesserit, sive quid ex ea re fructus pervenerit ad emptorem, ut ea omnia restituat. Item, si quas accesiones ipse praestiterit, ut recipiat. Item, si quod mancipium capitalem fraudem admiserit, mortis consciscendae sibi causa quid fecerit, inve arenam depugnandi causa ad bestias intromissus fuerit: ea omnia in venditione pronuntianto. Ex his enim causis judicium dabimus. Hoc amplius, si quis adversus ea sciens dolo malo vandidisse dicetur, judicium dabimus“.
} 
de animale de povară, iar unul se găsește în caz de a fi restituit, vom da o acțiune prin care vânzătorul să fie obligat să-și ia ambele animale înapoi”" .

Pornind de la textele romane, ca o primă condiție, reținem că garanția pentru vicii se impunea numai pentru viciile ascunse, edictul nefiind aplicabil pentru vicii aparente, adică acelea care puteau fi observate de cumpărător9 .

Așadar, vânzătorul era chemat să răspundă ori de câte ori lucrul vândut avea defecte care îl făceau, în tot sau în parte, impropriu întrebuințării sale $^{10}$. Aceasta constituie expresia amplorii viciului, doar viciile de o anumită însemnătate fiind susceptibile să antreneze răspunderea vânzătorului. Erau luate în considerare defectele, afecţiunile fizice (boli ale plămânilor, ficatului, prezența unei tumore, un beteșug etc.), iar nu și cele morale (timiditatea excesivă, superstițiozitatea, predispoziția pentru jocuri de noroc, băutură sau ceartă $)^{11}$.

Răspunderea vânzătorului era angajată doar pentru viciile preexistente contractului de vânzare, dar care se iveau după predarea lucrului.

Cumpărătorul putea intenta împotriva vânzătorului actio redhibitoria, care făcea parte din categoria acțiunilor arbitrare, în termen de

${ }^{8}$ D.21.1.38: „qui jumenta vendunt: palam recte dicunto quid in quoque eorum morbi, vitiique sit: uti quae optime ornata vendendi causa fuerint, ita emptoribus tradentur. Si quid ita factum non erit, de ornamentis restituendis, jumentisve ornamentorum nomine redhibendis, in diebus sexaginta: morbi autem vitiive causa inemptis faciendis, in sex mensibus, vel quo minoris, cum venirent, fuerint, in anno judicium dabimus. Si jumenta paria simul venierint, et alterum in ea causa fuerit ut redhiberi debeat, judicium dabimus, quo utrumque redhibeatur".

9 D.21.1.1.6.

${ }^{10}$ D.21.1.1.8: „proinde si quid tale fuerit vitii, sive morbi, quod usum ministeriumque hominis impediat, id dabit redhibitioni locum“ (Astfel, dacă viciul sau boala este de aşa fel încât ne împiedică să putem trage vreun folos sau vreun serviciu de pe urma sclavului, va fi loc pentru restituire").

${ }^{11}$ R. Zimmermann, op.cit., p. 313-314. 
şase luni utile de la momentul ivirii viciului ${ }^{12}$. Calea acţiunii nu era deschisă doar ca urmare a manifestării viciilor nedeclarate de vânzător, ci și atunci când o anumită calitate a lucrului, a cărei existență fusese garantată de vânzător, lipsea sau atunci când se ivea un defect a cărui lipsă fusese garantată de vânzător ${ }^{13}$.

Cumpărătorul pretindea vânzătorului restituirea prețului și a accesoriilor în schimbul restituirii lucrului. Dacă cel dintâi refuza restituirea prețului și a accesoriilor, în virtutea caracterului arbitrar al acțiunii, urma a fi condamnat la dublul acestora ${ }^{14}$. Ca efect al restituirilor reciproce, părțile erau repuse în situația anterioară încheierii vânzăriii ${ }^{15}$. De aceea, edictul de mancipiis vendundis prevedea că părțile trebuiau să țină cont, una față de cealaltă, de aspecte precum vătămările aduse sclavului de cumpărător sau plățile pe care cumpărătorul a fost obligat să le facă anterior restiuirii sclavului (ca urmare a admiterii unei acțiuni noxale, spre exemplu). Actio redhibitoria reprezenta, aşadar, o acțiune în rezoluțiune.

Obligația de garanție sancționată prin actio redhibitoria cuprindea atât viciile cunoscute și tăinuite de vânzător, cât și pe cele necunoscute acestuia ${ }^{16}$. Sistemul edililor curuli se deosebește de dreptul civil și sub acest aspect, imprimând răspunderii vânzătorului un caracter obiectiv, acesta fiind prezumat a-şi cunoaște marfa.

\footnotetext{
${ }^{12}$ Idem, p. 318.

13 Idem, p. 317.

14 D.21.1.45.

15 D.21.1.23.7 şi 21.1.6o.

${ }^{16}$ D.21.1.1.2.
} 
Deși implicau un grad sporit de severitate pentru vânzător, edictele edililor curuli au fost extinse la toate vânzările, indiferent de obiectul acestora, pentru că ofereau deplină sancțiune obligației vânzătorului de a preda posesiunea utilă a lucrului.

Nu este cert momentul de la care actio redhibitoria a putut fi intentată de orice cumpărător, contra oricărui vânzător, cu privire la orice lucru vândut. Se arată, într-un text atribuit lui Ulpian ${ }^{17}$, că acțiunea fusese generalizată încă din vremea jurisconsultului Marcus Antistius Labeo ${ }^{18}$. In literatura de specialitate s-au exprimat însă rezerve, afirmându-se că textul în cauză a fost interpolat $^{19}$ și că extinderea sferei de aplicare a acțiunii a intervenit mult mai târziu, odată cu elaborarea Digestelor.

III. Legiuirile adoptate în cea de-a doua fază a regimului turco-fanariot

\section{A. Codul Calimach}

Codul Calimach, promulgat în 1817, s-a aplicat pe teritoriul Moldovei până în 1865, când a fost abrogat ca efect al intrării în vigoare a Codului civil $\operatorname{din} 1864^{20}$.

\footnotetext{
17 D.21.1.1.pr.

18 Anii 54 î.e.n-10/11 e.n.

19 P.F. Girard, op.cit., p. 602, nota de subsol 2; V. Hanga - Drept privat roman, București, Editura Didactică și Pedagogică, 1978, p. 381, nota de subsol 3.

${ }^{20}$ Pe parcursul prezentei lucrări va fi avut în vedere conținutul Codului Calimach, astfel cum este redat în A.Rădulescu (coord.) - Codul Calimach, Ediție critică, Editura Academiei R.P.R., București, 1958
} 
Textele relevante pentru prezenta analiză sunt cuprinse între articolele 1240 și 1245, la care se adaugă textul art.1250.

Terminologia utilizată de legiuitor pentru acordarea garanţiei împotriva viciilor este comună cu cea utilizată pentru garanția împotriva evicțiunii, respectiv „darea chezășiei”. Conform art.1240, „acela ce au tăinuit < ne> obicinuitele metehne sau însărcinări a lucrului, [...], acela ce mințește zicând că lucrul este destoinic pentru o hotărâtă întrebuințare sau că este slobod de obicinuitele metehne și însărcinări, rămâne răspunzătoriu pentru aceasta, dacă se va arăta din împotrivă”.

Astfel, existența unor vicii, denumite „metehne” sau „însărcinări”, ori însuşiri ale bunului vândut, în măsura în care erau fie tăinuite, fie prezentate în mod nereal, atrăgeau răspunderea vânzătorului.

$\mathrm{Cu}$ titlu prealabil, reținem că vânzătorul va răspunde numai pentru metehnele ascunse ale lucrului, care nu ar fi putut fi observate ex propriis sensibus la momentul predării, cu excepția situației în care, convențional, s-a garantat și pentru asemenea vicii, astfel cum rezultă din cuprinsul art.1245 ${ }^{21}$.

Pe cale de consecință, răspunderea vânzătorului era atrasă numai pentru viciile ascunse tăinuite sau prezentate nereal.

Codul Calimach reglementează o serie de situații speciale, denumite prezumții, prin intermediul cărora apariția viciilor într-un interval determinat va conduce la atragerea răspunderii vânzătorului. Astfel, conform art.1241, „dacă o vită va începe a se bolnăvi ori de va pieri în curgere de 24 de

\footnotetext{
21 Art.1245 din Codul Calimach: „Dacă metehnele unui lucru sunt văzute, atunce n-are loc închizăşluirea afară numai dacă s-a dat anume făgăduință, că lucrul este slobod de toată meteahna și însărcinarea”.
} 
ceasuri după trădarea ei, atunce se socotește după presumția iuridică, că au fost bolnavă mai înainte de trădare”. În mod similar, art.1242 stabilește termene diferite pentru afecțiunile survenite în cazul vânzării de porci, vite albe, cai și vite de povară ${ }^{22}$.

Aceste reguli particulare au natura determinării duratei maxime în interiorul căreia se poate ivi viciul pentru a atrage răspunderea vânzătorului.

Dreptul de a obține rezoluțiunea vânzării pentru incidența viciului este expres prevăzut de art.1250, care stipulează „dacă meteahna sau lipsa lucrului va fi de acest feliu, încât să nu mai fie cu putință a o lecui sau îndeplini și prin aceasta va împiedica obicinuita întrebuințare a lucrului aceluia, atunce poate vătămatul să ceară desăvârşita anularisire a tocmelii”.

Pe cale de consecință, ca și actio redhibitoria din dreptul roman, acțiunea prevăzută de art.1250 din Codul Calimach dă posibilitatea cumpărătorului de a obține rezoluțiunea vânzării pentru viciile ascunse ale lucrului vândut.

22 Art.1242 din Codul Calimach: „Această presumție are tărie: a) când în curgere de 8 zile la porci se va arăta linți și la oi vărsat sau rîe sau dacă în curgere de două luni de zile se va descoperi gălbază la oi; b) când la vite albe se va ivi în curgere de 30 de zile după trădarea lor știriia vacilor și veneriia buhailor; c) când la cai și la vite de povară, în curgere de 15 zile după trădarea lor se va descoperi, răpciugă, buba mânzului, cum și nădușala, sau dacă în curgere de 30 de zile se va descoperi turba cailor, malicu, nărav rău, albața neagră fără de leac, pohăiala”. 


\section{B. Legiuirea Caragea}

Legiuirea Caragea a intrat în vigoare, potrivit pitacului domnesc de promulgare, la 1 septembrie 1818, și s-a aplicat în Țara Românească până la abrogarea ei prin Codul civil din $1864^{23}$.

Prin raportare la obiectul prezentei analize, dispozițiile relevante se găsesc în Partea a III-a, intitulată „De obște pentru tocmeli”, capitolul II, „Pentru vânzări”, în articolele 39-43. Din acestea se pot desprinde atât condițiile, cât și efectele desființării contractului de vânzare pentru vicii, chiar dacă terminologia apare ca străină Legiuirii Caragea.

Astfel, potrivit art.39, alin.1 din Partea a III-a, cap.II, „[d]e nu va arăta vânzătoriul zminteala lucrului ce vinde și la urmă se va vedea, iaste slobod cumpărătoriul să nu ia lucrul sau să scază din preț”.

Cu titlu prealabil, observăm că obligația de garanție pentru vicii poartă asupra oricărui bun ce poate forma obiect al contractului de vânzarecumpărare.

Prin urmare, dreptul vânzătorului de a refuza primirea lucrului ori de a plăti un preț redus exista numai în cazul unui viciu ascuns, fie tăinuit de vânzător, fie necunoscut de acesta. Amploarea viciului rezulta din alineatul 2 al aceluiași articol, respectiv lucrul trebuia să rămână „a fi netrebnic sau cu anevoe a fi de trebuința", aşadar să fi fost inapt a servi, în mod obişnuit, scopului pentru care a fost achiziționat. În acord cu criteriile de dimensionare a viciului existente în dreptul roman post-clasic, astfel cum au fost anterior

\footnotetext{
23 Pe parcursul prezentei lucrări este avut în vedere conținutul Legiuirii Caragea, astfel cum este redat în A.Rădulescu (coord.) - Legiuirea Caragea, Ediție Critică, Editura Academiei R.P.R., București, 1957.
} 
redate, reținem că nici în Legiuirea Caragea lipsa unor calități ale bunului vândut nu echivala cu vicii ale acestuia.

Mai mult, teza finală a art.39, alin.2 stipula lipsa unui drept la acţiune din partea vânzătorului în situația în care viciul nu era apt să determine inutilizarea bunului: „alminteri, să rămîe vânzătoriul nesupărat”.

În plus, Legiuirea Caragea excludea expres incidența garanției pentru viciile aparente, după cum rezultă din cuprinsul art.40, care prevedea că vânzătorul nu se învinovățește pentru „zmintelile cele învederate (cum ochiu stricat al unui cal și alte asemenea)”. La fel ca și în cazul edictului de jumentis vendundis, observăm că elementul de raportare al legiuitorului, prin exemplificarea utilizată în cuprinsul textului, este reprezentată tot de animale de povară. Apreciem că se impune o distincție între viciile aparente, care pot fi observate şi de către cumpărător ex propriis sensibus, și cele „învederate”, adică aduse la cunoștință de către vânzător. Incidența acestor prevederi în materia viciilor rezultate din vânzarea de vite și animale de povară rezultă și din dispozițiile art.42, alin.2, care fac referire la vânzarea unei turme „zmreduite” (afectate de o molimă).

Art.40 face referire la „zmintelile învederate”; în opinia noastră, acesta era incident numai în situația în care se proba indicarea respectivelor vicii de către vânzător premergător încheierii contractului. Partea finală a articolului, cuprinzând sintagma „pentru că cumpărătoriul nu poate pretinde că nu le-a văzut" nu este de natură a conduce la o concluzie contrară, cu atât mai mult cu cât observarea eventualelor vicii era în sarcina cumpărătorului la preluarea lucrului, iar învederarea acestora de către vânzător năștea o prezumție relativă în sensul cunoașterii ori posibilității de cunoaștere a lor de către cumpărător. 
În sprijinul diferențierii între viciile aparente și învederate vin şi prevederile art.41, care stipulează că „orice zminteală se va socoti, că cumpărătorul putea să o vază, să o cunoască sau să o bănuiască, nu poate pentru aceasta să pricinuiască”. Astfel, viciile aparente ori cele care puteau fi descoperite cu minime diligențe nu sunt susceptibile de a determina incidente în executarea contractului. În ceea ce privește viciile aparente, perceptibile ex proprïs sensibus, respectiv „zmintelile pe care cumpărătorul putea să le vază sau să le cunoască”, observăm că soluția Legiuirii Caragea este conformă canoanelor dreptului roman post-clasic, întrucât pentru acestea nu se putea atrage garanția vânzătorului. Situația este diferită în privința „zmintelilor pe care cumpărătorul putea să le bănuiască”, întrucât acestea sunt situate la granița dintre un viciu ascuns și unul aparent.

După aprecierea noastră, textul nu introduce un criteriu nou de raportare, ci desemnează, într-o manieră ușor imprecisă, acele vicii aparente ce puteau fi observate la o examinare diligentă, incluzând aici viciile care puteau fi deduse dintr-o eventuală lipsă de reacție a animalului la sunete (lipsa auzului), ori din maniera deficitară în care a fost construit ori întreținut un car, fapt uşor de sesizat la probarea acestuia.

Pe cale de consecință, putem conchide că în Legiuirea Caragea răspunderea pentru vicii putea fi atrasă numai pentru vicii ascunse ale lucrului vândut, care nu puteau fi observate la o examinare diligentă a acestuia.

Referitor la momentul existenței viciului, din formularea art.39, alin.1 din Partea a III-a, cap. II, deducem că viciul trebuie să preexiste vânzării, chiar dacă efectele sale nu au fost manifestate până la momentul încheierii contractului. 
Spre deosebire de dreptul roman post-clasic, legiuirea nu prevede un termen, ulterior contractului, până la care se poate invoca apariția viciului și valorifica obligația de garanție a vânzătorului.

În ceea ce privește efectele garanției pentru vicii, reglementarea relevantă se regăsește în art.39, alin.1, din Partea a III-a, cap.II conform căreia „iaste slobod cumpărătorul să nu ia lucrul sau să scază din preț”. Observăm că în urma constatării existenței unui viciu ascuns, cumpărătorul are alegerea între reducerea prețului plătit şi omisiunea de a lua lucrul. Nu putem interpreta această din urmă sintagmă ca fiind echivalentă cu desființarea contractului, în condițiile în care omisiunea de a lua bunul vândut, respectiv omisiunea de preluare are ca premisă lipsa predării anterioare.

Reamintim faptul că în Legiuirea Caragea, contractul de vânzare cumpărare avea ca premisă acordul de voință al părților, însă pentru încheierea sa valabilă (desăvârşirea vânzării) era necesar, în cazul bunurilor mobile, să opereze predarea bunului de către vânzător și predarea sau promisiunea predării prețului de către cumpărător ${ }^{24}$, ori ca una dintre părți să fi început executarea propriei obligații ${ }^{25}$. În cazul bunurilor imobile, contractul se încheia în mod valabil atunci când vânzătorul, primind prețul ori promisiunea plății prețului, remitea cumpărătorului zapisul vânzăriii ${ }^{26}$.

\footnotetext{
24 Astfel cum rezultă din cuprinsul art.12, alin.1 din Partea a III-a, Capitolul II din Legiuirea Caragea: „Vânzarea celor mișcătoare, atunci e săvârşită când cel ce vinde va da lucrul în mâna cumpărătorului, și cumpărătorul lui va da prețul, sau încredințare pentru preț”.

25 Conform art.12, alin.2 din Partea a III-a, Capitolul II din Legiuirea Caragea: „Desăvârșit vânzare este, și când vânzătorul singur începe a da lucrul, sau cumpărătorul singur a da prețul”. 26 Conform art.12 din Partea a III-a, Capitolul II din Legiuirea Caragea: „Vânzarea celor nemișcătoare, atunci e săvârșită, când vânzătorul primind prețul, sau încredințare pentru preț, va da cumpărătorului zapisul vânzării”.
} 
Pe cale de consecință, în cazul ivirii unui viciu ascuns, cumpărătorul avea dreptul de a refuza preluarea lucrului vândut, fapt posibil numai în cazul în care obligația de predare era afectată de un termen, ori în cazul în care prețul fusese plătit iar lucrul nepreluat.

Ulterior remiterii materiale a lucrului mobil, ori ulterior remiterii zapisului vânzării pentru imobile, garanția pentru vicii acordată în condițiile art.39, alin.1, din Partea a III-a, cap.II din Legiuirea Caragea nu mai era incidentă.

Această concluzie apare ca validată de prevederile art.15 și 16 din Legiuire, care stabilesc, în esență, că orice „bine sau vătămare” privitoare la bunul vândut, anterior săvârșirii vânzării revin vânzătorului, iar ulterior săvârşirii vânzării, „orice bine” revine cumpărătorului.

În plus, în cazul existenței unor servituți ce grevează bunul imobil vândut, legiuitorul recunoaşte în mod expres dreptul cumpărătorului de a obține desființarea contractului: „slobod iaste cumpărătorul să strice vânzarea sau să scază din preț”27, terminologie net diferită de cea utilizată în cazul garanției pentru vicii, fapt de natură a confirma concluzia noastră, anterior expusă.

Așadar, art.39, alin.1, din Partea a III-a, cap.II din Legiuirea Caragea nu recunoaște o desființare a contractului pentru surveniența de vicii ascunse, ci justifică refuzul executării obligației de preluare a bunului vândut, refuz incident numai în situația existenței unui termen, ca modalitate a obligației, ori în caz de plată prealabilă a prețului de către cumpărător, anterior preluării

${ }^{27}$ Astfel cum stipulează art.43 din Partea a III-a, Capitolul II din Legiuirea Caragea 
lucrului. În acest din urmă caz, refuzul preluării dă dreptul la restituirea prețului plătit.

Textul expres care consacră actio redhibitoria în Legiuirea lui Caragea este regăsit la cauzele de desființare ale contractului de vânzare cumpărare, respectiv art.44, din Partea a III-a, cap.II, care stipulează „stricarea” contractului când „se va găsi că are zminteală lucrul cel cumpărat și nu o va spune vânzătorul și va vrea cumpărătoriul să strice vânzarea”.

Pe cale de consecință, dacă lucrul vândut este afectat de un viciu ascuns, descoperit anterior predării, cumpărătorul este în drept să refuze primirea bunului ori să ceară o reducere a prețului, iar dacă viciul este descoperit după predarea bunului, cumpărătorul are dreptul de a solicita desființarea contractului.

O ultimă problemă în materia efectelor privește distincția dintre vânzătorul care cunoștea și cel care nu cunoștea existența viciilor, alături de limitele obligației acestora. Reținem că art.42, alin.1 reglementeză: „Când vânzătoriul va ști sminteala lucrului și o va tăcea, și dintr-aceasta se va întâmpla pagubă cumpărătoriului, se îndatorează la pagubă; iar când nu o va şti nu se îndatorează”.

Observăm că textul stipulează un drept la despăgubire al cumpărătorului, distinct de executarea sau desființarea contractului. În această situație, vânzătorul răspundea numai pentru omisiunea intenționată de a încunoștința cumpărătorul despre existența viciului. 


\section{Codul civil din 1864 și Codul civil din 2009}

\section{A. Răspunderea pentru vicii ascunse}

Mecanismul răspunderii pentru vicii ascunse, desăvârşit prin crearea actio redhibitoria, a fost preluat și în Codul civil român din $1864^{28}$.

Conținutul art. 1352 face ca orice argumente în sprijinul continuității instituției romane a garanției contra viciilor ascunse să fie de prisos. Acesta prevedea că „vânzătorul este supus la răspundere pentru viciile ascunse ale lucrului vândut, dacă din cauza acelora, lucrul nu este bun de întrebuințat, după destinarea sa, sau intrebuinţarea sa e atât de micşorată, încât se poate presupune că cumpărătorul nu l-ar fi cumpărat, sau n-ar fi dat pe dansul ceea ce a dat, de i-ar fi cunoscut viciile”.

Art. 1353, urmărind linia comentariilor jurisconsulților romani asupra edictelor edililor curuli, excludea viciile aparente din sfera celor pentru care vânzătorul datora garanție, pentru că acestea erau sau puteau fi cunoscute de cumpărător.

Viciul trebuia să fie grav, astfel cum se arăta în art. 1352, și să existe la momentul încheierii contractului de vânzare, căci din acel moment încolo riscul trecea asupra cumpărătorului ${ }^{29}$.

${ }^{28}$ Promulgat la 4 decembrie 1864 , intrat în vigoare la 1 iulie 1865.

29 D. Alexandresco - Explicațiunea teoretică și practică a dreptului civil român în comparațiune cu legile vechi şi cu principalele legislațiuni străine, tomul VIII, partea a II-a, București, Atelierele grafice Socec \& Co., Soc. Anon, 1925, p. 344. 
Asemenea edictelor edililor curuli, garanția era datorată atât de vânzătorul de rea-credință, cât și de cel care nu cunoștea existența viciilor ${ }^{30}$ (art. 1354).

Sediul materiei acțiunii redhibitorii și al acțiunii quanti minoris (la cu cât mai puțin) era dat de art. 1355, potrivit căruia „în cazurile art. 1352 și 1354, cumpărătorul poate sau a întoarce lucrul și a-și primi prețul, sau a opri lucrul și a cere înapoierea unei părți din preț arbitrată prin experți”.

Cumpărătorului îi era recunoscută libertatea de a alege acțiunea pe care urma să o intenteze, pornind de la împrejurarea că ar fi fost foarte dificil de apreciat gravitatea viciului ${ }^{31}$.

Acțiunea putea fi intentată împotriva vânzătorului originar și de subdobânditor ${ }^{32}$. Pare că această posibilitate exista și în dreptul roman, pornind de la conținutul edictului de mancipiis vendundis, precitat.

În cazul unui viciu ascuns, cumpărătorul putea solicita rezoluțiunea vânzării și restituirea prețului, alături de daune-interese (doar de la vânzătorul de rea-credință), în schimbul restituirii lucrului. Dacă avea interesul de a-l păstra, putând fi folosit chiar în ciuda defectelor, atunci el pretindea doar restituirea unei părți din prețul plătit, prin ipoteză superior valorii reale a lucrului.

${ }^{30}$ Idem, p. 354.

${ }^{31}$ Idem, p. 355.

${ }^{32}$ Idem, p. 354 nota de subsol 3. 


\section{B. Moștenirea edililor curuli}

Moștenirea edililor curuli dăinuie în Codul civil din 200933, art.1707, alin.1 prevăzând că „vânzătorul garantează cumpărătorul contra oricăror vicii ascunse care fac bunul vândut impropriu întrebuințării la care este destinat sau care îi micşorează în asemenea măsură întrebuințarea sau valoarea încât, dacă le-ar fi cunoscut, cumpărătorul nu ar fi cumpărat sau ar fi dat un preț mai mic".

Caracterul ascuns al viciilor, momentul la care acestea trebuie să existe și necunoașterea lor de către cumpărător sunt reglementate de alin.2-4 ale aceluiași articol.

33 Legea nr. 287/2009 privind Codul civil a fost publicată în M. Of., partea I nr. 511/24.07.2009. Ulterior, aceasta a fost modificată prin Legea nr. 71/2011 pentru punerea în aplicare a Legii nr. 287/2009 privind Codul civil, publicată în M. Of., partea I nr. 409/10.06.2011, apoi modificată şi rectificată (M. Of., partea I nr. 427/17.06.2011 şi M. Of., partea I nr. 489/8.07.2011), precum şi republicată în temeiul art. 218 din aceasta. După intrarea sa în vigoare, Codul civil a fost modificat și completat succesiv şi încă o dată rectificat în M. Of. nr. 246/29.04.2013, prin următoarele acte normative: Legea nr. 60/2012 privind aprobarea Ordonanței de urgență a Guvernului nr. 79/2011 pentru reglementarea unor măsuri necesare intrării în vigoare a Legii nr. 287/2009 privind Codul civil, publicată în M. Of., partea I nr. 255/17.04.2012; Legea nr. 138/2014 pentru modificarea şi completarea Legii nr. 134/2010 privind Codul de procedură civilă, precum şi pentru modificarea şi completarea unor acte normative conexe, publicată în M. Of., partea I nr.753/16.10.2014; Ordonanța de urgență nr. 1/2016 pentru modificarea Legii nr. 134/2010 privind Codul de procedură civilă, precum și a unor acte normative conexe, publicată în M. Of., partea I nr. 85/04.02.2016, modificată și completată la rândul său prin Legea nr. 17/2017 privind aprobarea Ordonanței de urgență a Guvernului nr. 1/2016 pentru modificarea Legii nr. 134/2010 privind Codul de procedură civilă, precum și a unor acte normative conexe, publicată în M. Of., partea I nr. 196/21.03.2017. 
Garanția vânzătorului își conservă caracterul obiectiv prin art.1708, alin.134. În plus, vânzătorul de rea-credință datorează şi daune-interese, conform art.1712, alin.1, spre deosebire de cel care nu cunoaşte viciul și care trebuie să restituie doar prețul și cheltuielile vânzării, după cum rezultă din art.1712, alin.2.

Liberei alegeri între desființarea vânzării, ca efect al intentării acțiunii redhibitorii, sau obținerea diferenței între prețul plătit și valoarea reală a lucrului, i-ar putea fi astăzi opus următorul argument: art.1710, alin.1 consacră mai întâi actio quanti minoris, la lit. c) şi doar apoi actio redhibitoria, la lit d), ierarhia fiind conturată prin alin.2 al aceluiaşi articol, cu ajutorul criteriilor gravității viciilor și scopului încheierii contractului, alături de alte împrejurări. Altfel spus, rezoluțiunea ar putea fi obținută doar dacă viciul afectează într-atât de tare bunul vândut, încât imprimă neexecutării obligației de predare un caracter însemnat, fapt stipulat expres în art.1551, alin.1.

Pe lângă rezoluțiunea vânzării, sunt expres reglementate dreptul la repararea sau înlocuirea bunului, conform art.1710, alin.1, lit. a-b, acestea având natura unor remedii actuale.

\section{Concluzii}

După cum am observat la momentul analizei edictelor edililor curuli, apărute în dreptul vechi, actio redhibitoria a fost creată pentru a permite desființarea contractului de vânzare-cumpărare ce avea ca obiect sclavi sau

34 D. Chirică - Tratat de drept civil. Contracte speciale. Vol. I Vânzarea şi schimbul, ed. a 2-a, revizuită, București, Ed. Hamangiu, 2017, p. 399. 
vite mari, în cazul existenței unor vicii ascunse care făceau lucrurile inapte să fie utilizate conform destinației obișnuite.

În urma generalizării acțiunii pentru orice fel de vânzare, cel târziu în dreptul post-clasic, acțiunea redhibitorie a devenit un instrument obișnuit pentru protecția cumpărătorului vătămat prin defectele necunoscute ale bunului vândut.

Influența acestei instituții asupra dreptului românesc este evidentă în epoca modernă, începând cu cea de-a doua fază a regimului turco-fanariot până la Codul civil contemporan.

$\mathrm{Cu}$ titlu particular, reținem că în Codul Calimach și în Legiuirea Caragea dreptul de a obține rezoluțiunea contractului pentru vicii era recunoscut pentru orice tocmeli de vânzare, fără a se face distincție în funcție de felul lucrului vândut, însă normele speciale din cuprinsul acestor legiuiri stabilesc reguli distincte pentru vânzarea de vite albe, vite mari, ori vite de povară.

Aceasta este, indubitabil, o reminiscență a textelor romane din epoca clasică, în cuprinsul cărora acțiunea redhibitorie era des utilizată în privința vânzărilor de jumenta.

În Codurile civile moderne, reglementarea garanției pentru vicii apare ca desprinsă din conținutul Digestelor, ulterior generalizării acțiunii redhibitorii pentru orice fel de vânzări.

În toate cele patru legiuiri românești observăm că răspunderea este atrasă numai pentru vicii ascunse, care nu puteau fi observate în mod direct de către cumpărător și care existau la momentul vânzării, chiar dacă nu se manifestaseră, fapt conform regulilor din dreptul post-clasic. 
Un alt element constant vizează amploarea viciului, fiind esențial ca acesta să determine imposibilitatea utilizării în tot sau în parte a bunului conform scopului avut în vedere de cumpărător.

În ceea ce privește efectele, independent de terminologia utilizată de legiuitorul român, respectiv „anularisire a tocmelii”, „stricarea vânzării”, „întoarcerea lucrului şi primirea prețului”, ori rezoluțiune, reținem că acțiunea redhibitorie determină desființarea contractului prin repunerea părților în situația anterioară, fapt neschimbat în fizionomia instituției.

Precum în dreptul roman, observăm că legiuitorul român a preluat ca şi criteriu de determinare a severităţii răspunderii vânzătorului cunoaşterea de către acesta a viciilor, fiind prevăzute limite diferite în funcție de buna sau reaua credință a acestuia.

Toate aceste elemente conduc la concluzia unei continuităţi între dreptul roman şi dreptul civil modern, care acreditează teza dreptului viu, aflat într-o continuă evoluție și adaptare la realităţile sociale.

Analiza punctuală a particularităților actio redhibitoria şi a modului în care aceasta a influențat dreptul românesc nu trebuie să constituie decât un exemplu al importanţei dreptului roman pentru formarea şi evoluţia dreptului național, întrucât asemenea continuităţi se regăsesc în aproape toate instituțiile dreptului privat modern. 